\title{
Transcription factors controlling responses to toxic chemicals
}

\author{
P. Godoy $\cdot$ R. Reif
}

Published online: 1 December 2012

(c) Springer-Verlag Berlin Heidelberg 2012

In this issue, Paul Jennings from Innsbruck, Martin Leonard from Dublin, and colleagues contribute a comprehensive review about transcriptional response in toxicological insult (Jennings et al. 2012; this issue). Currently, gene array analyses are frequently used to study responses of cell or tissues to chemicals (Park et al. 2011; Sun et al. 2011; Heise et al. 2012; Godoy et al. 2010; Bolt et al. 2010). Moreover, gene expression profiling has been successfully used to characterize tumor tissue (Schmidt et al. 2011, 2012; Cadenas et al. 2010). However, it has become clear that powerful biostatistical tools are required to better understand the complex gene expression patterns. One possibility is pre-clustering gene groups according to biological motifs (Schmidt et al. 2008; Kammers et al. 2011; Cadenas 2012). A particularly powerful tool to obtain an overview over complex gene expression profiles is identification of the responsible transcription factors (Zellmer et al. 2010; Glahn et al. 2008). For this purpose, statistical tools are available that identify overrepresented transcription factor binding sites from lists of differential genes. Often this approach helps to reduce long lists of genes differentially expressed in response to test compound exposures to a small number of responsible (candidate) transcription factors and helps to obtain an overview how cells or tissues react to a specific toxicological insult. The successful introduction of software for identification of over-represented transcription factor binding sites leads to an increased interest in the role of individual transcription

P. Godoy $(\bowtie) \cdot$ R. Reif

Leibniz Institut für Arbeitsforschung an der TU Dortmund,

Leibniz Research Centre for Working Environment

and Human Factors (IfADo), Ardeystrasse 67,

44139 Dortmund, Germany

e-mail: godoy@ifado.de factors. The current review of Jennings and colleagues gives a comprehensive overview of transcription factors relevant for responses to toxic compounds:

- NFE2L2 (Nrf2)

- NFE2L1 (Nrf1)

- AHR

- P53

- NF-KB

- STAT

- HIF

- MTF

- HSF

- The nuclear receptor subfamily responsible for the unfolded protein response

The review is of high interest to anyone studying gene expression profiles and transcriptional regulation. Considering the high relevance of this topic, we are pleased that in addition to the comprehensive review of Jennings and colleagues, Mel Anderson from Research Triangle Park contributes a minireview on transcription factor-governed molecular pathways in toxicology (Andersen 2012; this issue).

\section{References}

Andersen M (2012) Toxicogenomics for Transcription Factor-Governed Molecular Pathways: moving on to Roles beyond Classification and Prediction. Arch Toxicol (this issue)

Bolt HM, Marchan R, Hengstler JG (2010) Gene array screening for identification of drugs with low levels of adverse side effects. Arch Toxicol 84(4):253-254

Cadenas C (2012) Prognostic signatures of breast cancer: Perou's molecular subtypes and Schmidt's metagenes. EXCLI J 11:204-207

Cadenas C, Franckenstein D, Schmidt M, Gehrmann M, Hermes M, Geppert B, Schormann W, Maccoux LJ, Schug M, Schumann A, Wilhelm C, Freis E, Ickstadt K, Rahnenführer J, Baumbach JI, 
Sickmann A, Hengstler JG (2010) Role of thioredoxin reductase 1 and thioredoxin interacting protein in prognosis of breast cancer. Breast Cancer Res 12(3):R44

Glahn F, Schmidt-Heck W, Zellmer S, Guthke R, Wiese J, Golka K, Hergenröder R, Degen GH, Lehmann T, Hermes M, Schormann W, Brulport M, Bauer A, Bedawy E, Gebhardt R, Hengstler JG, Foth H (2008) Cadmium, cobalt and lead cause stress response, cell cycle deregulation and increased steroid as well as xenobiotic metabolism in primary normal human bronchial epithelial cells which is coordinated by at least nine transcription factors. Arch Toxicol 82(8):513-524

Godoy P, Lakkapamu S, Schug M, Bauer A, Stewart JD, Bedawi E, Hammad S, Amin J, Marchan R, Schormann W, Maccoux L, von Recklinghausen I, Reif R, Hengstler JG (2010) Dexamethasonedependent versus -independent markers of epithelial to mesenchymal transition in primary hepatocytes. Biol Chem 391(1):73-83

Heise T, Schug M, Storm D, Ellinger-Ziegelbauer H, Ahr HJ, Hellwig B, Rahnenfuhrer J, Ghallab A, Guenther G, Sisnaiske J, Reif R, Godoy P, Mielke H, Gundert-Remy U, Lampen A, Oberemm A, Hengstler JG (2012) In vitro-in vivo correlation of gene expression alterations induced by liver carcinogens. Curr Med Chem 19(11):1721-1730

Jennings P, Limonciel A, Felice L and Leonard MO (2012) An overview of transcriptional regulation in response to toxicological insult. Arch Toxicol. doi:10.1007/s00204-012-0919-y (this issue)

Kammers K, Lang M, Hengstler JG, Schmidt M, Rahnenführer J (2011) Survival models with preclustered gene groups as covariates. BMC Bioinf 12:478

Park HJ, Oh JH, Park SM, Cho JW, Yum YN, Park SN, Yoon DY, Yoon S (2011) Identification of biomarkers of chemically induced hepatocarcinogenesis in rasH2 mice by toxicogenomic analysis. Arch Toxicol 85(12):1627-1640

Schmidt M, Böhm D, von Törne C, Steiner E, Puhl A, Pilch H, Lehr HA, Hengstler JG, Kölbl H, Gehrmann M (2008) The humoral immune system has a key prognostic impact in node-negative breast cancer. Cancer Res 68(13):5405-5413

Schmidt M, Petry IB, Böhm D, Lebrecht A, von Törne C, Gebhard S, Gerhold-Ay A, Cotarelo C, Battista M, Schormann W, Freis E, Selinski S, Ickstadt K, Rahnenführer J, Sebastian M, Schuler M, Koelbl H, Gehrmann M, Hengstler JG (2011) Ep-CAM RNA expression predicts metastasis-free survival in three cohorts of untreated node-negative breast cancer. Breast Cancer Res Treat 125(3):637-646

Schmidt M, Hellwig B, Hammad S, Othman A, Lohr M, Chen Z, Boehm D, Gebhard S, Petry I, Lebrecht A, Cadenas C, Marchan R, Stewart JD, Solbach C, Holmberg L, Edlund K, Kultima HG, Rody A, Berglund A, Lambe M, Isaksson A, Botling J, Karn T, Müller V, Gerhold-Ay A, Cotarelo C, Sebastian M, Kronenwett R, Bojar H, Lehr HA, Sahin U, Koelbl H, Gehrmann M, Micke P, Rahnenführer J, Hengstler JG (2012) A comprehensive analysis of human gene expression profiles identifies stromal immunoglobulin $\kappa \mathrm{C}$ as a compatible prognostic marker in human solid tumors. Clin Cancer Res 18(9):2695-2703

Sun Z, Niu R, Wang B, Jiao Z, Wang J, Zhang J, Wang S, Wang J (2011) Fluoride-induced apoptosis and gene expression profiling in mice sperm in vivo. Arch Toxicol 85(11):1441-1452

Zellmer S, Schmidt-Heck W, Godoy P, Weng H, Meyer C, Lehmann T, Sparna T, Schormann W, Hammad S, Kreutz C, Timmer J, von Weizsäcker F, Thürmann PA, Merfort I, Guthke R, Dooley S, Hengstler JG, Gebhardt R (2010) Transcription factors ETF, $\mathrm{E} 2 \mathrm{~F}$, and SP-1 are involved in cytokine-independent proliferation of murine hepatocytes. Hepatology 52(6):2127-2136 